\title{
Health in school program: from training processes to practice scenarios
}

\begin{abstract}
Mirna Neyara Alexandre de Sá Barreto Marinho, ${ }^{1,2}$, Neiva Francenely Cunha Vieira ${ }^{3}$, Heraldo Simões Ferreira ${ }^{4}$, Alice Maria Correia Pequeno ${ }^{5}$, Itamara da Costa Sousa ${ }^{6}$, Antônia Priscila Pereira ${ }^{7}$, Aretha Feitosa de Araújo ${ }^{2,8}$, Maria de Fátima Antero Sousa Machado ${ }^{9}$
\end{abstract}

${ }^{1}$ Enfermeira, mestre em ensino na saúde pela Universidade Estadual do Ceará (UECE) - Fortaleza (CE), Brasil.

2Membro técnico do Grupo de Pesquisa Clínica, Cuidado e Gestão em Saúde (GPCLIN) da Universidade Regional do Cariri (URCA) - Crato (CE), Brasil.

${ }^{3}$ Enfermeira, $\mathrm{PhD}$. Bolsista de produtividade do CNPQ (nível 2), Professora titular da Universidade Federal do Ceará (UFC) - Fortaleza (CE), Brasil.

${ }^{4}$ Educador físico, PhD. Professor adjunto da UECE - Fortaleza (CE), Brasil.

${ }^{5}$ Geóloga, doutora em saúde pública. Professora permanente do Curso de Mestrado Profissional Ensino na Saúde (CMEPES) da UECE - Fortaleza (CE), Brasil.

${ }^{6}$ Enfermeira, mestre em enfermagem. Professora da Faculdade Estácio Juazeiro do Norte (CE), Brasil.

${ }^{7}$ Enfermeira, mestranda em enfermagem. Membro do Grupo de Pesquisa em Saúde Coletiva (GRUPESC) da URCA - Crato (CE), Brasil.

${ }^{8}$ Enfermeira, mestre em ensino na saúde pela UECE. Doutoranda do Programa de Pós-Graduação em Cuidados Clínicos em enfermagem e saúde da UECE- Fortaleza (CE), Brasil.

${ }^{9}$ Enfermeira, Doutora em enfermagem. Professora associada da URCA - Líder do GRUPESC da URCA - Crato (CE), Brasil.

\begin{abstract}
Introduction: The Health in School Program (PSE) is an intersectoral policy between the ministries of health and education with the perspective of integral attention (prevention, promotion and attention) to the health of children, adolescents and young people in basic public education, within the framework of schools and basic health units. It has five structural components to be developed by professionals, who need ongoing training to reach their goals and goals.

Objective: To analyse the training process of PSE health and education professionals.

Methods: Qualitative research, based on the theoretical framework of Paulo Freire, whose epistemological categories were compiled by Ecco (reading of the world, significant themes, dialogue, curiosity and problematization). Collection of data was conducted through an interview with 45 professionals and analysed.
\end{abstract}

Results: The reading of the world in relation to the training was permeated with doubts regarding the work with the adolescents. Regarding the significant themes, they expressed an interest in studying some content for the particularities of this publication. The dialogue was encouraged in the transfer of the information and determinations established by management. As for the curiosity, the professionals pointed out uncertainties about the continuity of the actions of the programme and reported learning needs that were not contemplated. The problematization was not evident in the speeches.

Conclusion: There are gaps in the professional formation in the PSE for an action that considers the promotion of health in adolescents.

Keywords: school health, health promotion, adolescent, continued education.

\section{Corresponding author:}

mirna.neyara@bol.com.br

Manuscript received: January 2018

Manuscript accepted: June 2018

Version of record online: June 2018

Suggested citation: Marinho MNASB, Vieira NFC, Ferreira HS, Pequeno AMC, Sousa IC, Pereira AP, et al. Health in school program: from training processes to practice scenarios. J Hum Growth Dev. 2018; 28(2):175-182. DOI: http://dx.doi.org/10.7322/jhgd.147219 


\section{INTRODUCTION}

The Health in School Program (PSE) is an intersectoral policy in which the ministries of health and education work together from the perspective of integral care (prevention, promotion and attention) for the health of Brazilian public basic education students in schools and/or Basic Health Units (UBS) of the Unified Health System (SUS) ${ }^{1}$.

Five components structure the PSE, and the third component involves the permanent education and training of education and health professionals, children, adolescents and young people, with efforts to enable the training of professionals in the municipal settings to work with the target public, aiming at aligning the discourse and actions developed ${ }^{2}$.

The field of qualification of professionals inserted in SUS has been endorsed by social movements, legislation and public policies that advocate for the strengthening of teaching-service-community integration, with Permanent Health Education (EPS) as a strategy for the reorganisation of training practices, attention, management, and formulation of policies and social control in the health sector, through intersectoral actions and changes in health education that involve the participation of different social actors $^{3}$. In this sense, the training of professionals in the PSE helps to meet the health demands of children, adolescents and young people from the perspective of integral care.

Because the creation of the programme is still considered recent, and its expansion throughout the country has been gradual, studies have not identified the formation of the professionals involved in this context to

\section{METHODS}

\section{a) Study design}

The research is descriptive of a qualitative approach, which comprises reality from the critical analysis of processes, structures, perceptions, products and results when considering the perception of social actors with the possibility of transforming their life contexts ${ }^{8}$.

\section{b) Scenario and study participants}

The study was carried out in the municipalities of Barbalha, Crato and Juazeiro do Norte, also known as the Metropolitan Region of Cariri (RMC) and located in the south of the state of Ceará, Brazil.

According to the National Register of Health Establishments (CNES), Barbalha has 23 health posts, Crato has 31 units classified as centres and health posts and Juazeiro do Norte has 47 UBS. The number of teams in the Family Health Strategy (ESF) is 23, 40 and 76, respectively. Regarding the number of schools, there are 84 in Barbalha, 79 in Crato and 113 in Juazeiro do Norte.

There were no records of professionals with PSE training in the municipalities, and so the units participating in Health Week at School (SSE) were chosen to be studied in 2013, reaching a total of 11 schools and ESF in Barbalha, 12 in Crato and 15 in Juazeiro do Norte.

The professionals participating in the study were members of the FHS and the schools, two from each execute actions that relate to the local context. Training is an important part of achieving the assumptions established by the ministries and therefore is a challenge for the consolidation of the proposal.

Paulo Freire's bases were used as a theoretical reference for the construction of knowledge, related to the epistemological categories found in his works, compiled and denominated by $\mathrm{Ecco}^{4}$ as world reading, significant themes, dialogue, curiosity and problematization.

Thinking about the perception of the world, in Freire's conception ${ }^{5}$, everyone is able to analyse their reality, and knowledge coming from practice is not enough. The significant themes have a transforming character, promoting the integration of knowledge and social transformation ${ }^{6}$. Dialogue is intrinsically linked to the word, which, authentically reflected, generates commitment and modifies reality ${ }^{6}$. Curiosity is understood by the intensity with which the human being intends to know/unveil phenomena, events, relationships, and realities that present themselves as challenging ${ }^{4}$. Problematization advocates the transformation of a dominant society to a more just one, from the description of a concrete reality, the clash of its contradictions and the possibility of confrontation ${ }^{7}$.

Considering this perspective, the relevance of this research lies in the contribution to the chosen scenario and also to other municipalities that need to improve the work in the PSE from the training of professionals. The aim of this study was to analyse the training process of the professionals involved in the PSE to deal with the health demands of the adolescent.

municipality (totalling six schools and six ESF), which were intentionally included in the investigation due to being linked with the PSE for more than six months, participation in training and/or SSE shares in the year of collection and for being working during the period. Thus, a total of 52 subjects were enrolled, of which 45 participated in the study, of which 25 were Professionals of Education (PE) and 20 were Professionals of Health (PS). Only 16 declare PSE training.

\section{c) Data collection and organisation}

The collection took place between the months of September 2013 and January 2014 through semi-structured, recorded interviews, conducted in a single meeting with each participant, with an average duration of 15 minutes. The interviews were transcribed and organised according to Paulo Freire's theoretical framework of knowledge construction.

For this, the categories of the study were the epistemological categories themselves (reading of world, significant themes, dialogue, curiosity and problematization), and they were referred to as analytical by the established theoretical foundation and based on the evidence constructed according to the object of investigation. The following board presents the categories and evidence that guided the process of organisation (Figure 1). 
Figure 1: Categories and evidence of the study

\begin{tabular}{|ll|}
\hline $\begin{array}{l}\text { Epistemological or analytical categories } \\
\text { Reading of world }\end{array}$ & $\begin{array}{l}\text { Interview evidences (coming from the theoretical framework) } \\
\text { Perception of professionals about their training process for the } \\
\text { program. }\end{array}$ \\
Significant themes & $\begin{array}{l}\text { Suggested/desired themes based on lived reality; Issues arising } \\
\text { from the actions already carried out in the PSE. }\end{array}$ \\
& $\begin{array}{l}\text { Listening to the demands and difficulties in the formative } \\
\text { processes and in the accomplishment of the actions; Exchange } \\
\text { of experiences and transfer of information received in training } \\
\text { processes or in other situations; Interaction in the formative } \\
\text { processes; Information about the training carried out by the } \\
\text { management. } \\
\text { Doubts raised in the program's formation or participation; Meeting } \\
\text { the learning needs of professionals; Participation/motivation/ } \\
\text { interest reported in the training processes. } \\
\text { Strategies and learning methodologies used. }\end{array}$ \\
Problematization &
\end{tabular}

RMC - Ceará, Brazil, 2013

d) Data analysis

The evidence extracted from the interviews correlated to each epistemological/analytical category used to obtain the worldview of the professionals regarding the formative process of acting in the programme, the significant thematic determinants in the learning process considering its reality, the dimension of the dialogue and the curiosity in the practices and in the formation, as well as the problematization in the sense of understanding the use of this as active methodology of teaching and learning during the formative processes.

\section{RESULTS}

\section{Category 1. Reading of world}

Perception of professionals about their training process for the programme

The perception of the professionals about their training process to work in the PSE was related to their personal knowledge and experiences thus far in professional practice, the completion of some courses involving adolescent and academic formation.

"(...)Many years that I work in the community, many years that I work in a hospital, then we learn many things"

(PS. 10).

"(...)We bring it to the bag that you learned in college, the studies and what we live" (PS. 20).

"We use more of the knowledge that we have of experience, of experience, of situations that we have already experienced within the school in the classroom and even of our formation as a person" (PE. 1).

They recognise, however, uncertainty and limitations regarding the development of activities in the PES.

"(...)We should have more skills mainly to work in this age group." (PS. 14).

"So we are not trained and qualified for this issue of dealing with adolescent health" (PE. 1).

“(...)I have no deepening, no knowledge about the program" (PE. 15).
In addition to the works of Paulo Freire and the authors who share his theories/studies on adolescence and health, adolescent health policies, health promotion and the PSE.

\section{e) Ethical aspects}

This study obtained a favourable opinion from the Ethics and Research Committee of the State University of Ceará under protocol number 357.437.

\section{RESULTS}

\section{Category 2. Significant themes}

\section{Suggested/desired themes based on reality}

The professionals highlighted various subjects, such as: sexuality and gender, gestation, drugs, metabolism, healthy eating, body hygiene, oral health and even the programme itself.

"I believe that more knowledge about the program (...)" (PS. 7).

"(...)Alcohol and drugs (...) sexually transmitted diseases" (PE. 6).

“(...)Human reproduction and sexuality could be worked" (PE. 23).

"(...)Healthy food, oral and body hygiene as well (...)" (PE. 25).

Issues arising from the actions already carried out in the PSE

They emphasised the issues arising from the actions carried out, especially those developed in the SSE, such as: nutritional assessment, healthy eating, visual acuity, sex education, peace culture, oral hygiene, alcohol and other drugs.

"The first thing we did was to check the nutritional status of these adolescents in school, and the second activity we did the assessment of visual acuity" (PS. 12).

“(...)Healthy eating, sex education, peace culture, and especially we made the nutritional evaluation of these students" (PS. 15). 


\section{Category 3. Dialogue}

Listening to demands and difficulties in the formative processes and in the completion of the actions

The reports indicate that there was no time for debate in the formations and that the opinion of those who carried out the activities was not valued. However, they listened to what management was saying about the programme during the meetings.

"But it was a very quick thing in the training, had many doubts that were not answered (...)" (PS. 14).

"(...)Most of the time the actions of the PSE are ready for us. Look, you guys are going to have to do this!" (PS. 15).

"We even suggested other topics, but they said no" (PS. 22).

\section{Exchange of experiences and transfer of information received in training processes or in other situations}

In the UBS, these moments occurred under the direction of the nurses and, in the schools, with the participants of the groups.

"The nurse, he held meetings with the ACS, he joined those who had not gone to training and he passed all the information(...)"

(PS. 1).

"(...)There are the formations for some professionals here of the education and when they return to school they transfer to us what was put there(...)" (PE. 7).

\section{Interaction in the formative processes}

At the meetings, these moments occurred with the objective of transferring strategies by the management, and in the group's participants mentioned little or no interaction (due to superficiality, short duration and formality).

“(...)We go to meetings and just present work strategies" (PS. 15).

"(...)Often, those in the front are worried about simply fulfilling a formality" (PE. 1). "(...)This month the person in charge came to talk about the actions, the importance of the actions(...). But so a very superficial thing, a matter of 15 minutes in the training" (PE. 15).

\section{Information about the training carried out by the management}

There was participation and knowledge of the training processes in some scenarios, but other participants were completely unaware.

"Since I attended the first week of training for the PSE provided by the municipality from there to here I was not aware of any other specific training" (PS. 16).

"(...)It is always in the past the formation, the place, with whom it is, which people should participate, and always we send people to participate" (PE. 7).

"(...)I do not know the question of training for the teacher to work in the PSE (...)" (PE. 21).

\section{Curiosity}

Doubts raised in training or programme participation
The doubts and concerns were related to the programme's performance, due to the lack of knowledge about what behaviours would be engaged in with adolescents after the actions.

"But after you've done all this? What was the result, what was the counterpart?"

(PS. 10).

“(...)Honestly I think it's very flawed because then, we go there and do the screening and nobody knows what's done after(...)" (PS. 17).

"(...)So prevention is done, but then what happens?(...)" (PE. 18).

\section{Meeting the learning needs of professionals}

The attendance to the learning needs of the professionals was not achieved, either because of a disability or because there was no training in the PSE.

“(...)You never had any training, it would be great if you had one. My learning needs have not been addressed" (PS. 2).

“(...)Need more clarification. I believe so, a training, something like this, so we can update ourselves more" (PS. 7).

The discourses of education professionals are related to the difficulties encountered by not specialising in the area of health or experiencing work overload.

"There are many needs, because those who are not from the health area (...). Do you need more information. More meetings, to get more knowledge" (PE. 11).

"Not because he did not want to. It is because of the many attributions that we already have here at school (...) is a weight" (PE. 15).

In this context, they demonstrated the individual search for the realisation of knowledge related to the PSE through Internet research and guidance from other professionals.

"(...)So the advances in training for me were in the particular sense even, I seek to inform myself, look at the Ministry of Health about the program" (PS. 14).

"We try to talk to health professionals (...)" (PE. 7).

\section{Participation/motivation/interest reported in the training processes}

Some mentioned restricted or partial participation in the training processes, and others showed greater interest.

\section{Problematization \\ Strategies and learning methodologies used}

“(...)My participation was only a listener, we did not practice there with the doctor did not" (PS.12).

“(...)In the formations I listen, participate and question" (PS.15).

"My participation occurred in the formation of the groups, so each group was discussing actions relevant to the problems found in the school" (PE. 3).

“(...)I participated going” (PE.16). 
Certain lines point to training based on traditional aspects of education.

"It was a talk with the program, the age group of the program and how we should work" (PS. 14).

"Meetings are always called by management and are always conducted by it too" (PS. 15).

Others pointed out a greater approximation with active strategies of teachers' education, in order to attain a more expressive participation by the professionals; however, they did not contemplate problematization in its essence.

\section{DISCUSSION}

There is a radical difference between training and practicing, because training is deeper, bringing a precise need to transform people's consciousness, increasing intuitive curiosity and broadening critical ability 9 . From this perspective, the expression "training" was adopted in this study.

The professionals pointed out that the PSE training was insufficient to meet the demands and needs of adolescents by citing their life experiences, academic experiences and work with adolescents in other programmes. The lack of minimal training outlined by the ministries was articulated by these professionals, who said that it compromises the appropriate direction for this policy.

A passivity on the part of the professionals involved in education was observed, because they understood that they do not have the abilities to teach certain subjects in the health area. It is convenient to think of a permanent formation and oriented in fact by the context, thinking about the demands of professionals and adolescents.

Research carried out with the professionals who are part of the National Program for Improving Access and Quality of Primary Care on the components of the PSE point out that actions related to the training of professionals are not very effective and that this is a fundamental condition for the subjects who work in schools and UBS. Furthermore, they highlight the need to hire professionals from the most diverse backgrounds and specialties, with skills in health promotion actions, contributing to the work of those who are involved in the daily lives of adolescents ${ }^{10}$.

When referring to the topics that they would like to be included in the training, the professionals highlighted the knowledge gaps and the context of the adolescents' lives, pointing out situations of vulnerability. Biological contents were emphasised, so that professionals did not know or did not understand the relevance of other themes relevant to the public use of the programme.

A significant theme emerges not only from investigation of ideas under a given context, but rather, from asking the interested parties why they are studying the subject, analysing the "how" and the "why"11.

It is convenient to expand the concept of health manifested by professionals, since it is beyond biological factors, encompassing determinants and health determinants ${ }^{12}$. Furthermore, there is a need to
“(...)Meetings were held, talk wheels, how the program will be passed on to the students, in the PSE program, and then we put it into practice" (PS. 13).

"We had workshops and lectures, we had a week of training and it was very interesting" (PS. 18).

"(...)Forming groups, and each group discussed the actions there to work with students, with adolescents" (PE. 3).

understand the adolescent as a potential being with many particularities that acts and reacts differently in the most diverse situations and who must be considered in his or her multidimensionality and singularity ${ }^{13}$. This comprehensive look would certainly lead to the identification of other issues in the daily work process.

The themes implemented were aimed at carrying out the activities agreed upon in the PSE, disregarding the knowledge gaps of the interviewees and the context of the school adolescents, as well as deficiencies in the framework of these formations, since the aforementioned content should have already been executed through the coordination of the programme.

Regarding dialogue, listening was facilitated at the ESF's internal meetings, in which the participants reviewed their goals and determinations, and in some situations, it was possible to speak to the professionals. However, some opinions were not considered, given that it was a vertical dialogue. Due to the scarce formations that occurred and to the fact that not all the subjects of the study participated, listening at these moments was rarely mentioned. This led to deficiencies, because the doubts were not remedied.

It is important to emphasise that establishing a pedagogical relationship based on reflexive dialogue strengthens the teaching-learning process with positive results for the subjects involved in the pedagogical action, besides the gains for the target audience ${ }^{14}$.

Regarding the exchange of experiences and information transfer, these were mentioned in the ESF and in schools, especially the need to share the activities that would be developed in the school context with the adolescents. At the ESF, this exchange was attributed to the unit's nurses, their educational potential and the direct supervision of community health agents (ACS). From this perspective, studies consider the nurse as an educator in health who has an great relevance in the ESF in terms of training and perfecting the ACS to work with the population ${ }^{15,16}$.

Concerning this interaction, it was mentioned that the formations are of a more bureaucratic order, offering, in turn, little relevance to the professional scenarios. When dialogue occurs in these educational moments as a relational tool, with an approximation between educators and learners and awareness of the responsibility of their roles, there is a greater understanding of the object studied 
due to an expansion of the exercise of freedom with a creative and transformative insertion ${ }^{17}$.

Regarding communication about carrying out the formative processes of the PSE, there were divergences in the discussions, since some professionals were aware of these moments and others were not aware of any formative activity. Dialogue is an essential element in this context, so that concrete communication between the different actors can be achieved. Communication directly reflects the quality, continuity and achievement of the work, the satisfaction of the professionals' needs and the development of teamwork ${ }^{18}$. From this point of view, dialogue needs to be made possible in a broader dimension than that presented in the scenarios studied.

The doubts raised about the development of the work in the PSE were directed only to the continuity of the actions. The professionals did not present questions about the subjects inherent to the programme, nor were they given opportunities in the formations that would allow the exercise of curiosity.

Educational practice should be able to provide learners with curiosity in order to make them more critical, thereby producing knowledge in collaboration with others, providing creative situations for knowledge and making the educational act authentic ${ }^{19}$.

It is understood that there was not a deepinvestigation by the local management aiming to ascertain the learning needs of these professionals. There is, therefore, a barrier between those who plan (management and coordination) and those who execute (service professionals) these activities. Formation must be sustained in dialogue, discussion and debate, requiring consideration of the knowledge of individuals, understanding that history is a process of participation of $\mathrm{al}^{16}$.

The professionals totally blamed management for this deficiency, without considering the commitment that is also healthy to them in this scenario. Others presented a more active stance, seeking alternatives to contemplate the gaps that permeate their learning and demonstrating interest, commitment and seriousness with the work to be developed with adolescents.

It is emphasised that motivation needs to be considered, since it is a determining factor for learning. Thus, the intrinsic factors of the professionals need to be ascertained so that their particularities can be worked out. The extrinsic factors need a better systematisation of thinking about the content addressed, relating it to the working contexts of the professionals, as well as using appropriate methodologies and strategies for each theme.

\section{CONCLUSION}

In every training process, a commitment is made to carry out the survey of the topics of interest of the target audience with contextualization so that knowledge is improved and brings meaning to the contexts of action. Dialogue needs to be made possible not only in listening, but also in the planning, execution, monitoring and evaluation of activities, allowing horizontality in the relationships and commitment of those involved. Curiosity, to overcome the dimension of naivety also requires this participation, especially from the perspective
Reinforcing this prerogative, Tronchin and colleagues ${ }^{20}$ point out that in the adult learning process, the need to know why content and concepts are being studied emerges, that that learning happens more effectively in problem solving, and that motivation to learn is greater if it is intrinsic (individual) and if the content to be learned can be applied briefly.

The discussions signalled an awakening of curiosity when they mentioned the interest and the desire to learn and the questions raised, besides the participation in groups of discussion that broadens the desire to know, understanding other realities. In other discourses, aspects of a formation centred on the traditional approach to education, from the perspective of which the educator speaks and transmits their content without allowing for student participation and without arousing the curiosity necessary to this moment ${ }^{11}$.

Problematization presents itself as a methodological proposal that seeks a problem-oriented curriculum, broadening the view of other dimensions of reality, since it is not part of problems previously given, but rather, of the action-reflection-action of the students. For this, we need a method not focused on the theoretical discussion, but focused on the integration between the action and the reflection and practical transformations that result ${ }^{21}$. It finds its foundations particularly in the philosophy of praxis and in the liberating/problematizing pedagogy of Paulo Freire, in which the basic axis of orientation of the whole process refers to the action-reflection-transforming action $^{11}$.

When analysing the problematization category, it is noticed that the training is centred on the traditional education model of content transmission without participation/collaboration of the professionals, in order to alert them to meaningful learning in their context of action. In this context, the articulators of the training for the PSE need to think about and develop an educational proposal that values the knowledge of the professionals, including specific situations that have been experienced, so that all can equally participate in this process.

Educational strategies have been mentioned, such as workshops, talk wheels and group work, to give opportunities to exchange ideas, suggestions and opinions for certain contexts related to adolescents. However, it is emphasised that the active teaching-learning methodologies, represented by problem-based learning and problem-solving, are not being worked out in this scenario $^{21}$.

of co-responsibility that becomes effective the more one is awakened to reality.

Teaching strategies are favourable in certain situations. However, in terms of a comprehensive proposal with many nuances, as is that of the PSE, problematization should be used, because it is a methodology that gives the question, the questioning, the reflection and, above all, the social transformation.

It is necessary to have a grassroots organisation to discuss the programme, to analyse it and to reflect 
on the impact that the actions developed have provided. Filling the gaps in knowledge from the use of collective knowledge of health and education, with reflection and rupture of paradigms, contemplating the participation and constant integration of all the actors involved and seeking to bring to these scenarios the framework of the epistemological categories. And also aiming at a motivating and differentiated formation with advances in the promotion of adolescent health in several facets.

\section{REFERENCES}

1. Ferreira IRC, Moysés SJ, França BHS, Carvalho ML, Moysés ST. Percepções de gestores locais sobre a intersetorialidade no Programa Saúde na Escola. Rev Bras Educ. 2014;19(56):61-76. DOI: http://dx.doi.org/10.1590/S1413-24782014000100004

2. Machado WD, Oliveira KMCP, Cunha CG, Araújo Júnior DG, Silvino RHS, Dias MSA. Programa Saúde na Escola: Um olhar sobre a avaliação dos componentes. Rev Sanare. 2016;15(1):62-8.

3. Oliveira MPR, Menezes IHCF, Sousa LM, Peixoto MRG. Formação e qualificação de profissionais de saúde: Fatores associados à qualidade da atenção primária. Rev Bras Educ Med. 2016;40(4):47- 59. DOI: http://dx.doi.org/10.1590/1981-52712015v40n4e02492014

4. Ecco I. O conhecimento na Pedagogia Freireana como suporte teórico para a educação escolar formal. In: Educação: visão crítica e perspectiva de mudança. VI Congresso Internacional de Educação. Concórdia: 2007.

5. Freire PRN. A importância do ato de ler: em três artigos que se completam. 51. ed. São Paulo: Cortez; 2011.

6. Freire PRN. Pedagogia do oprimido. 50 ed. Rio de Janeiro: Paz e Terra; 2011.

7. Freire PRN. Educação e mudança. 2. ed. rev. São Paulo: Paz e Terra; 2011.

8. Minayo MCS. O desafio do conhecimento: pesquisa qualitativa em saúde. 14 ed. São Paulo: Hucitec; 2014.

9. Freire PRN, Freire N, Oliveira WF. Pedagogia da solidariedade. São Paulo: Villa das Letras; 2009.

10. Machado MFAS, Gubert FA, Meyer APGFV, Sampaio YPCC, Dias MSA, Almeida AMB, et al. The health school program: a health promotion strategy in primary care in Brazil. J Hum Growth Dev. 2015;25(3):307-12. DOI: http://dx.doi.org/10.7322/jhgd.96709

11. Freire PRN. Pedagogia da autonomia: saberes necessários à prática educativa. 43. ed. São Paulo: Paz e Terra; 2011.

12. Leite CT, Machado MFAS, Vieira RP, Marinho MNASB, Monteiro CFS. The school health program: teachers' perceptions. Invest Educ Enferm. 2015;33(2):280-87. DOI: http://dx.doi.org/10.17533/udea.iee.v33n2a10

13. Silva IR, Gomes AMT, Valadares GV, Santos NLP, Silva TP, Leite JL. Nurses' perceptions of the vulnerabilities to STD/AIDS in light of the process of adolescence. Rev. Gaúcha Enferm. 2015;36(3):728. DOI: http://dx.doi.org/10.1590/1983-1447.2015.03.47293

14. Lima MM, Reibnitz KS, Kloh D, Vendruscolo C, Corrêa AB. Dialogue: Network that intertwines the pedagogical relationship into the practical-reflective teaching. Rev Bras Enferm. 2016;69(4):610-7. DOI: http://dx.doi.org/10.1590/0034-7167.2016690406i

15. Pinheiro SJ, Lucas FEQ, Barreto LF, Cruz MRCM, Pereira FGF, Barbosa AL. Conceptions of health education practices in the context of Nursing Education. Rev Rene. 2016;17(4):545-52. DOI: http://dx.doi.org/10.15253/2175-6783.2016000400015

16. Barbiani R, Nora CRD, Schaefer R. Nursing practices in the primary health care context: a scoping review. Rev Latino-Am. Enfermagem. 2016;24:e2721. DOI: http://dx.doi.org/10.1590/1518-8345.0880.2721

17. Almeida ER, Moutinho CB, Leite MTS. Family health nurses' teaching practice in the health education development. Interface. 2016;20(57):389-401. DOI: http://dx.doi.org/10.1590/1807-57622015.0128

18. Broca PV, Ferreira MA. Processo de comunicação na equipe de enfermagem fundamentado no diálogo entre Berlo e King. Esc Anna Nery. 2015;19(3):467-74. DOI: http://dx.doi.org/10.5935/1414-8145.20150062

19. Freire PRN. Pedagogia do compromisso. São Paulo: Villa das Letras; 2008.

20. Tronchin DMR, Peres HHC, Lima AFC, Alavarce DC, Prata AP, Santos MR, et al. Development of an online nursing management course: successful experience between Brazil and Portugal. Rev Esc Enferm USP. 2015;49(esp 2):162-7. DOI: http://dx.doi.org/10.1590/S0080-623420150000800023

21. Simon E, Jezine E, Vasconcelos EM, Ribeiro KSQS. Metodologias ativas de ensino-aprendizagem e educação popular: encontros e desencontros no contexto da formação dos profissionais de saúde. Interface. 2014;18(2):1355-64. DOI: http://dx.doi.org/10.1590/1807-57622013.0477 


\section{Resumo}

Introdução: O Programa Saúde na Escola (PSE) é uma política intersetorial entre os ministérios da saúde e da educação com a perspectiva da atenção integral (prevenção, promoção e atenção) à saúde de crianças, adolescentes e jovens do ensino público básico, no âmbito das escolas e unidades básicas de saúde. Possui cinco componentes estruturantes a serem desenvolvidos pelos profissionais, que necessitam de formação permanente para o alcance de seus objetivos e metas.

Objetivo: Analisar o processo de formação dos profissionais de saúde e educação do PSE.

Método: Pesquisa qualitativa, fundamentada no referencial teórico de Paulo Freire, cujas categorias epistemológicas foram compiladas por Ecco (leitura de mundo, temáticas significativas, diálogo, curiosidade e problematização). Coleta realizada por meio de entrevista com 45 profissionais e analisada a partir do referencial.

Resultados: A leitura de mundo em relação à formação apresentou-se permeada de dúvidas para o trabalho com os adolescentes. No tocante às temáticas significativas, manifestaram interesse em estudar alguns conteúdos pelas particularidades deste público. O diálogo foi incitado no repasse das informações e determinações estabelecidas pela gestão. Quanto à curiosidade, os profissionais apontaram incertezas acerca da continuidade das ações do programa, e relataram necessidades de aprendizagem não contempladas. A problematização não foi evidenciada nas falas.

Conclusão: Destacam-se lacunas na formação do profissional no PSE para uma atuação que considere a promoção de saúde do adolescente.

Palavras-chave: saúde escolar, promoção da saúde, adolescente, educação continuada.

๑ The authors (2018), this article is distributed under the terms of the Creative Commons Attribution 4.0 International License (http:// creativecommons.org/licenses/by/4.0/), which permits unrestricted use, distribution, and reproduction in any medium, provided you give appropriate credit to the original author(s) and the source, provide a link to the Creative Commons license, and indicate if changes were made. The Creative Commons Public Domain Dedication waiver (http://creativecommons.org/publicdomain/zero/ $1.0 /$ ) applies to the data made available in this article, unless otherwise stated. 